\title{
Features of the innovative and creative potential of future education specialists
}

\section{Características do potencial inovador e criativo dos futuros especialistas em educação}

\section{Características del potencial innovador y creativo de los futuros especialistas en educación}

\author{
Olena Kvas ${ }^{1}$ iD, Laryssa Zyazyun² iD, Zoriana Khalo ${ }^{3}$ iD
}

\author{
${ }^{1}$ Ivan Franko National University of Lviv, Lviv, Ukraine \\ ${ }^{2}$ Taras Shevchenko Kyiv National University, Kyiv, Ukraine \\ ${ }^{3}$ Drohobych Ivan Franko State Pedagogical University, Drohobych, Ukraine
}

Corresponding author:

Olena Kvas

Email: sylkinos@ukr.net

How to cite: Kvas, O., Zyazyun, L., \& Khalo, Z. (2021). Features of the innovative and creative potential of future education specialists. Revista Tempos e Espaços em Educação, 14(33), e16725.

http://dx.doi.org/10.20952/revtee.v14i33.16725

\begin{abstract}
The current state of economic and social development requires from a professional the ability not only to operate with a certain set of professional knowledge obtained in higher education, but also the formed creative opportunities, the ability to self-realization in further independent activity. Therefore, higher education institutions face an important problem of developing the creative potential of youth, which in turn involves the organization of the educational process taking into account the psychological patterns of development of the entire system of personal qualities in student age. Therefore, the problem of identifying the degree of formation of the creative and innovative potential of future managers and checking the effectiveness of the psychological and pedagogical conditions for their acquisition of professional competencies in this direction in the educational process is urgent. Taking this into account, the main purpose of the study is to find new ways to develop and stimulate the innovative and creative potential of future education managers. For this, the methods of theoretical analysis were used. As a result of the research, the basic principles of development and stimulation of the innovative and creative potential of future education managers were generalized and systematized.
\end{abstract}

Keywords: Creative potential. Education. Innovative potential. Pedagogy. Potential. 


\section{RESUMO}

O estado atual de desenvolvimento econômico e social exige de um profissional a capacidade não só de operar com um determinado conjunto de conhecimentos profissionais obtidos no ensino superior, mas também as oportunidades criativas formadas, a capacidade de autorrealização em atividades independentes futuras. Portanto, as instituições de ensino superior enfrentam um problema importante de desenvolvimento do potencial criativo dos jovens, que por sua vez envolve a organização do processo educacional levando em consideração os padrões psicológicos de desenvolvimento de todo o sistema de qualidades pessoais na idade do aluno. Portanto, torna-se urgente o problema de identificar o grau de formação do potencial criativo e inovador dos futuros gestores e verificar a eficácia das condições psicológicas e pedagógicas para a aquisição de competências profissionais neste sentido no processo educacional. Levando isso em consideração, o objetivo principal do estudo é encontrar novas formas de desenvolver e estimular o potencial inovador e criativo dos futuros gestores da educação. Para isso, foram utilizados os métodos de análise teórica. Como resultado da pesquisa, os princípios básicos de desenvolvimento e estimulação do potencial inovador e criativo dos futuros gestores da educação foram generalizados e sistematizados.

Palavras-chave: Educação. Pedagogia. Potencial criativo. Potencial inovador. Potencial.

\section{RESUMEN}

El estado actual de desarrollo económico y social requiere de un profesional la capacidad no solo para operar con un cierto conjunto de conocimientos profesionales obtenidos en la educación superior, sino también las oportunidades creativas formadas, la capacidad de autorrealización en una actividad independiente adicional. Por tanto, las instituciones de educación superior se enfrentan a un importante problema de desarrollo del potencial creativo de los jóvenes, que a su vez implica la organización del proceso educativo teniendo en cuenta los patrones psicológicos de desarrollo de todo el sistema de cualidades personales en edad de estudiante. Por tanto, urge el problema de identificar el grado de formación del potencial creativo e innovador de los futuros directivos y comprobar la efectividad de las condiciones psicológicas y pedagógicas para la adquisición de competencias profesionales en esta dirección en el proceso educativo. Teniendo esto en cuenta, el objetivo principal del estudio es encontrar nuevas formas de desarrollar y estimular el potencial innovador y creativo de los futuros gestores de la educación. Para ello, se utilizaron los métodos de análisis teórico. Como resultado de la investigación, se generalizaron y sistematizaron los principios básicos de desarrollo y estimulación del potencial innovador y creativo de los futuros gestores de educación.

Palabras clave: Educación. Pedagogía. Potencial creativo. Potencial inovador. Potencial.

\section{INTRODUCTION}

Personality-specific characteristics of a creative personality include, first of all, attempts to evaluate phenomena from an ethical point of view and some difficulty in communicating with others, due to their lack of understanding of the interests and experiences of the extraordinary personality. In addition, a creative person is characterized by manifestations of specific motivation, aimed primarily not at reproductive activities with the expected result, but at achieving a new, original solution, without fear of misunderstanding or condemnation from others. The analysis of the problem shows that the organization of the process of independent educational and cognitive work of students creates optimal conditions for the development of cognitive motivation of future professionals, helps not only to increase everyone's mental activity, but also to form students' orientation to realize their own creative potential. (Fedorov et. al., 2021)

So, the development of a student's creative and innovative potential is a significant pedagogical problem, primarily in view of the fact that it is seen as one of the conditions for 
conscious, practically oriented learning, an incentive to comprehend and comprehensive development of educational content. In the professional sphere, creative potential is realized as a trait, ensures the adaptation of a specialist to the conditions of activity, ensures professional selfdevelopment, and contributes to the formation of an individual style of activity. The higher the creative potential, the greater the variability of the choices, the more likely it is to choose the optimal solution for certain circumstances. Subsequently, as a person matures as a professional, his creative potential more and more manifests itself as a means of transforming not an employee under the influence of professional reality, but professional reality under the influence of an employee.

If we are talking about a manager, a manager, then such a need arises almost immediately after he takes up a position, since management is precisely aimed at coordinating the activities of an organization, a team with circumstances that not only objectively develop, but are also formed by means of internal and external tactics and strategy management. Psychologists define creative potential as an integrative property of a person, characterizes the measure of opportunities to carry out creative activity, readiness and ability for creative self-realization and self-development. The general structure of creative potential, in his opinion, is made up of: inclinations, inclinations, manifested in the provision of advantages to that; interests, their focus and frequency; curiosity, desire to create something new; speed in assimilating new information; manifestations of general intelligence; perseverance, dedication, hard work; relatively fast and high-quality mastery of skills, skills, mastery of performing certain actions; the ability to implement their own strategies and tactics for various problems facing the search for a way out of complex non-standard, extreme situations (Krumsvik, 2014).

At the same time, it is noted that the person himself is often not fully aware of his creative prospects, which means that he requires certain conditions in order for her creative potential to undergo proper development. Realizing the importance of the studied phenomenon for the professional skill of a manager, we believe that such conditions should be created in the process of professional training and we consider them as one of the factors for the success of this training. A creative manager, a successful manager is needed today, first of all in the economic sphere.

As experienced teachers of higher education point out, such a specialist can be trained by combining the efforts of a teacher and a student. To do this, "teachers must radically restructure the structure, methods and forms of student learning activities" in order to improve their practical training using innovative technologies and with a focus on independent work, which "provides the necessary quality of specialist training through the creative assimilation of knowledge and the formation of the ability to independently obtain and to replenish this knowledge".

How does the creative component of vocational training become more active in the conditions of modern higher education? As some scholars justly assert, it is the productive learning activity and the inclusion of the student in it that is a necessary condition for the development of the ability to create. " At the same time, "productive activity is possible only when the reproductive elements are included in the creative process of the subject (Marek et al, 2020).

Thus, for the successful development of the creative potential of a future manager in the educational process of higher education, it is necessary to apply such methods of educational activity that would ensure an optimal balance of reproductive and productive. However, practice shows that, despite all the obviousness of this requirement, we often meet an imbalance caused by two extremes. The first of them is an orientation towards information saturation, which does not find practical embodiment either in the actions or in the student's imagination through a separation from the real picture of professional activity. We mean, first of all, not an objective, but a subjective picture of it, that is, the student's idea of where, in what conditions and how the assimilated information he may need, what transformations it undergoes at the same time and how it will be woven into the canvas of other professionally significant information. The second extreme lies in 
the direction of the student to independently perform creative tasks without proper pedagogical support, methodological support, as a result of which a significant number of young people find themselves face to face with the problems of their professional development, go through trial and error where they exist, but are not always applied effective teaching technologies are able to focus on results without limiting initiatives. Moreover, the initiative appears exactly where there are necessary guidelines for it, while the ambiguity of the goal often leads to the attenuation of active search, and, consequently, creative activity. We believe that a student's independence in mastering a profession does not lose, but only becomes more productive if the system of his pedagogical support includes training sessions. Experts emphasize that the value of training technologies lies not only in the development of skills and professional practical activities, but also in the orientation of the teaching "not only and not so much to gain knowledge, but also to form the ability to create."

In our opinion, it is the training mini-model of professional activity that contributes to the psychological restructuring of a young person from a consumer, whom she mainly acted in educational activities, from a development subject, as required by labor activity. At the same time, training technologies are a kind of bridge between the general and the individual in professional training, which is very significant in the context of our research.

According to psychologists, the ability for a creative, unconventional approach to solving problems is not always a direct consequence of education and special training, and to a greater extent reflects the personality traits of a manager. Undoubtedly, the individual characteristics of a future manager are the basis of his creative abilities, but we cannot agree with the researcher that special training plays an almost tertiary role in their development. The personality is formed accordingly in the process of vocational training, and therefore, its professionally significant features acquire a more perfect form and are considered by us as one of the learning outcomes. Of course, one cannot deny the importance of purely individual prerequisites for the development of a manager's creative potential, in particular, the characteristics of his character.

As the researchers note, against the background of a variety of character types, it manifests itself in business activities (receptive, exploitative, greedy, exchange), the only fruitful orientation of character, which consists in the realization of the inherent capabilities of a person, "using one's strength, comprehending the world through love and reason. The main value of this type of character is a person, the full and fruitful development of her I. This is a loving, active, intelligent, creative type."

The list of qualities is not accidental. A person capable of productive activity, first of all, must be humane, interested in the social results of his activity. If she is focused only on herself, her interests should be egocentric, then the business efforts she makes usually carry traits of manipulativeness, and therefore, cause rejection from those whom they touch. Let us call such a person emotionally mediocre, deprived of the ability to be happy for others, and at the same time deeply understand their needs and interests. Could such a person have significant creativity? We believe that it is not, since it is deprived of the main thing - an adequate focus on a subordinate person, a partner person, a consumer person, is not able to look at the problem through their eyes, and therefore - to determine the direction of applying creative efforts. Researchers confirm the irreplaceability and rational component of creativity, in this case it is considered as a manifestation of the individual specifics of the manager's worldview (Kryshtanovych, Bilyk, Shayner, Barabash, Bondarenko, 2021).

But it is humanity as a personality trait that contributes to the fact that creativity does not turn into an end in itself, the innovativeness of the manager's strategy and tactics does not lead to unjustified risk. Therefore, defining the criteria for the development of the creative potential of a manager, the first of them should be called the corresponding orientation of his personality as the main reference point of this development. In general, we believe that, while carrying out pedagogical support of this development, it is advisable to take into account such aspects of it: 
humanistic-personal, reflecting the meaning of creativity; competence, which provides its content; activity-oriented, aimed at mastering the corresponding processes; analytical and evaluative, showing the ability for an adequate self-assessment of the subject of creativity, assessment of its results and significance in the integral process of solving professional problems.

\section{METHODOLOGY}

The main purpose of the study is to find new ways to develop and stimulate the innovative and creative potential of future education managers. For this, a number of methods were applied, which form the research methodology. The study was carried out using the following theoretical methods: systems analysis and synthesis, induction and deduction, comparison, classification, generalization and systematization, idealization and abstraction.

\section{RESULTS AND DISCUSSION}

Analysis of research on the problem of training managers shows that managerial potential is a component of his professional activity and determines the all-round development of his personality. Most scientists and researchers of professional activity and professional training of managers distinguish such social and psychological qualities that are significant for him: psychological competence, managerial culture, intelligence, leadership abilities, tolerance, the ability to manage conflicts, stress resistance, adaptability, time management skills (Fedorov, Paputkova, Ilaltdinova, Filchenkova, Solovyev, 2017).

In particular, some scholars, considering special competence, point out that two requirements should be defined (Cordeiro, et al 2021).:

1. Effective performance of professional functions of a manager, understanding of the nature of managerial work and management processes and the ability to think large-scale, forward-looking.

The structure of special competence in accordance with this requirement presupposes the following knowledge and skills: the ability to substantiate and make decisions in situations that are characterized by high dynamics; high information awareness in the development of the industry in which the company operates, the level of achievements in engineering, technology, competitiveness, dynamics of demand for products and services, etc.; the ability to effectively manage resources, plan and predict the work of an enterprise, mastering ways to improve management efficiency; the ability to use modern information technology, communication and communication methods.

2. Managers must have specific qualities that contribute to increasing trust and respect from those with whom they enter into relationships. Ability to work with people mastery of the art of establishing external relations; the ability to self-esteem, the ability to make the right choice, improve qualifications.

The structure of special competence in accordance with this requirement presupposes the following knowledge and skills: high sense of duty and dedication; honesty in relations with people and trust in partners; the ability to clearly express your thoughts and beliefs; attention and care to people, regardless of their position in the hierarchy of the organization; the ability to quickly replenish their physical and spiritual strength and critically assess their own activities. Isolation of previously unresolved parts of the general problem to which this article is devoted. Despite the sufficient level of scientific study of the problems of researching the leadership abilities and qualities of a specialist, some of their features still remain open for further scientific research.

However, in our opinion, in addition to these qualities, abilities and skills, a modern manager desperately needs developed leadership qualities not only at the level of awareness of leadership issues, but also as a component of his professional activity and managerial potential. 
The study of modern approaches to leadership issues, in particular in the context of the professional activities of managers, shows that a real leader is a team player, therefore readiness for collective interaction comes first among the components of leadership potential. In the context of considering this issue, we share the opinions of scientists who define "a leader as a person capable of inspiring and directing people and their emotions into creativity. The relationship between a leader and others should be viewed in a "resonant" manner. In other words, the stay of the leader with the followers on the same wavelength, thanks to which the members of the group will have a creative atmosphere, as a result of which the potential and professional level of each will grow, as well as the percentage of effectively solved problems. "

Scientists note that "building an effective team is becoming an integral part of a leader. Leadership varies depending on the task and the situation in accordance with the decision of the team. To increase the competitiveness of a specialist, it is necessary to form him as a resonant leader, in whose content the process of creating and functioning of a team as an integral component should be invested. That is, to launch three vector models of the concept of leadership for improvement: as a process, state and result, namely effective team building. "

In addition, modern managers are increasingly perceived as innovators who must have deep knowledge in various fields, and this knowledge must be constantly updated and updated.

Since all these qualities are quite difficult to combine in one person, a manager-leader should learn to be a leader of leaders, and therefore, the managerial competence of leaders of modern Ukrainian organizations or enterprises can be described using the following optimal leadership competencies (Kryshtanovych, Kryshtanovych, Stechkevych, Ivanytska, Huzii, 2020):

1. Willingness to take responsibility for the team.

2. Willingness to be responsible for the collective result, even in the event of failure.

3. The advantage of the overall result over the personal.

4. Positive attitude towards people.

5. Ability to learn, desire to develop.

6. Lack of fear of strong subordinates.

7. Ability and willingness to inspire.

8. Ability to hear others.

9. Willingness and ability to teach others.

10. Expert or excellent manager.

11. Ability to organize others.

12. Own point of view.

13. Willingness for unpopular decisions.

14. Resistance to stress.

15. Lack of desire to assert themselves at the expense of others.

Let's consider which of the leadership competencies belong to the category of those that are easy to form and correct, which cannot be changed and can be corrected, but difficult or long (Awe, Church, 2020).

1. Willingness to take responsibility for the team. Ponomarev's revisions on responsibility in the system of professional competence of a specialist seem to be fair. He believes that the responsibility of a manager should be expressed in an objective assessment of the performance of personnel and in ensuring social partnership and social protection of personnel. In most cases, this competence is difficult to develop, although it is possible to stimulate its manifestation by other factors (external assessment, recognition, money), but then you will have to pay too much attention to this issue and constantly keep the situation under control.

2. Willingness to be responsible for the collective result, even in the event of failure. It is difficult to develop this factor, however, if there is responsibility for personal results as a model of 
behavior, it is possible to change the paradigm. A sufficiently long-term control action will be required.

3. The advantage of the overall result over the personal. It can be quite easily adjusted by a competent system of motivation and constant reinforcement. To do this, you need to know the map of the motivators of a particular person.

4. Positive attitude towards people. This competence in an adult cannot be adjusted.

5. Ability to learn, desire to develop. It develops quite freely, if it does not conflict with natural abilities.

6. Lack of fear of strong subordinates. It largely depends on the focus on the overall result and self-confidence. In most cases, self-confidence can be increased by competent management actions.

7. Ability and willingness to inspire. Partly a natural gift, partly it can be taught.

8. Ability to hear others. Depends on the desire to find this competence. The second aspect is a certain set of skills (the ability to separate facts from hypotheses, the ability to hear without guessing the intentions of a person, etc.), which can be taught through mentoring or during trainings to develop communication skills.

9. Willingness and ability to teach others. Competence is difficult to acquire, since it requires a combination of patience, tact, well-delivered speech, the ability to correlate your level of knowledge with the level of knowledge of the student, the ability to explain vata, to consolidate, to give feedback. With good communication and decent presentation skills, the ability to persuade and influence, this competence can be developed quite easily.

Since the purpose of our research is to update interactive tools that provide a high level of managerial competence of the future manager by developing his innovative and creative potential.

In general, most diagnostic techniques are aimed at determining a person's ability to be a leader. The very same ability of a person to lead largely depends on the development of her organizational and communication skills.

Basically, by diagnosis, the following leadership signs are determined (Buldu, Armagan, 2019).:

- will and ability to overcome obstacles on the way to the goal;

- persistence, ability to take reasonable risks, patience, willingness to do monotonous, uninteresting work for a long time and well;

- initiative and desire to work without petty care - independence;

- mental stability does not give interest in unrealistic proposals;

- good adaptability to new conditions and requirements;

- self-criticism, a sober assessment not only of one's own successes, but also of failures;

- exactingness to yourself and others;

- criticality, the ability to see weaknesses in tempting offers;

- reliability, adherence to the word, you can rely on them;

- endurance, can work even under overload conditions;

- susceptibility to new things, a tendency to solve non-traditional problems with original methods;

- resistance to stress, does not lose self-control and performance in extreme situations;

- optimism, refers to difficulties as inevitable and surmountable obstacles;

- decisiveness, the ability to independently and make decisions, in critical situations to take responsibility for oneself;

- the ability to change styles of behavior depending on conditions.

The training of a modern education manager who is able to implement the ideas of personality-oriented education, to solve in an original way topical educational and sociocultural problems requires a special organization of his practical and mental activities. 
Susceptibility to new, innovative thinking is formed in a person at an early age, largely depends on the creative atmosphere in the family, focused on the innovative activities of kindergartens, schools and teachers who directly work with the child. Under favorable conditions, this potential significantly affects her further professional growth and life in general.

Professional orientation towards innovative activities is focused during training at an educational institution. We consider this period favorable for the development of a motivationalvalue attitude towards pedagogical innovations, although, as the analysis shows, many practicing teachers are characterized by a low level of formation of innovative behavior and readiness for innovative activity, to a large extent it is a product of traditional education in an educational institution.

In the context of the problem raised, it is of interest to consider the opinion that when shaping the innovative behavior of a teacher, and, accordingly, a future education manager, it is important to take into account the following principles (Bakhov, Ryzhykov, Kolisnyk, 2018):

1. The principle of the teacher's reflection on his own psychological and pedagogical experience (covers assessing the professional level, predicting professional success, organizing selfknowledge and self-diagnostics, maintaining stable operational feedback).

2. The principle of forming a teacher's orienting-search position on any aspects of his own and borrowed pedagogical experience.

3. The principle of forming a holistic approach to the analysis of problem pedagogical situations (the peculiarity of such situations in the modern educational space is the presence of a large number of participants with their own roles, methods of interaction and interests).

4. The principle of the formation of the ability to solve problems collegially with other participants (pupils, colleagues), which makes it possible to find optimal solutions not only by defending their own positions, but also by analyzing other proposals and generating them together.

We believe that the main principles of building the interaction of a teacher with masters in the formation of innovative behavior of future education managers in the modern educational space can be (Aleksieienko-Lemovska, 2019):

- the principle of freedom of choice or alternativeness (joint planning, differentiated tasks, etc.);

- the principle of personal orientation;

- the principle of adequacy (displaying the realities of the current stage of socio-economic development, taking into account possible and necessary changes, based on the interests of both the organization and each of its members);

- the principle of continuity and integrity of personality development;

- the principle of professional and practical orientation (we believe that it is pedagogical practice or internship that provides a combination of fundamental scientific-theoretical and practical-methodological directions in the training of future managers and contributes to the formation of a system of pedagogical and managerial skills, personal qualities and value attitudes on the scientific and pedagogical activities of undergraduates )

- the principle of professional and personal development in pedagogical interaction (reflection, correction of one's own activity);

- the principle of creative self-expression, cooperation and co-creation (for the development of cognitive and professional activity, creative self-expression of future managers, the creative atmosphere in the modern educational space plays an important role, which provides for free communication, exchange of thoughts, ideas, and most importantly - the personal attitude of future education managers to creativity).

Note that innovative teaching at the university convinces of the importance of such areas of development of the professional qualities of the future head of the educational institution as emotionality of thinking, the formation of a new type of communication and communicative 
abilities, the development of the ability for internal dialogue as the basis of self-knowledge, problematization of communication, change of its methods, change of roles.

\section{CONCLUSION}

A theoretical analysis of studies on the training of future managers in the field of education showed that this problem is in the focus of attention of researchers and is acquiring a pronounced interdisciplinary nature. In modern economic conditions, the ability of a manager and staff to generate, accept, develop and implement creative ideas, projects provides positive economic and technological effects, is the key to the formation of unique competitive advantages and innovative development of the education sector. According to the results of theoretical research, it was found that a significant part of students fully or partially do not meet the requirements of readiness to carry out creative and innovative professional activities. Therefore, there is an urgent need for the introduction of psychological and pedagogical technologies for the development of a creative personality and creative training in the professional training of future managers of the education sector, which can be carried out both in specially organized learning processes and in extracurricular activities.

So, we believe that a necessary condition for solving the problem posed in the educational environment of the university should be dominated by the spirit of innovative creativity and constant search. The implementation of the considered principles ensures consistency in preparing the education manager for innovative activities in the modern educational space in the process of methodological improvement of pedagogical skills and the development of the innovative culture of the future education manager, since it is these categories that are of fundamental importance for the choice of directions for the development of a personality and the implementation of its innovative potential.

Authors' Contributions: Kvas, O.: conception and design, acquisition of data, analysis and interpretation of data, drafting the article, critical review of important intellectual content; Zyazyun, L.: conception and design, drafting the article, critical review of important intellectual content; Khalo, Z.: conception and design, acquisition of data, analysis and interpretation of data, drafting the article, critical review of important intellectual content. All authors have read and approved the final version of the manuscript.

Ethics Approval: Not applicable.

Acknowledgments: Not applicable.

\section{REFERENCES}

Awe, O.A. And Church, E.M. (2020), "Project flexibility and creativity: the moderating role of training utility", Management Decision, Vol. ahead-of-print No. ahead-of-print. DOI: https://doi.org/10.1108/MD-02-2020-0226

Aleksieienko-Lemovska, L. (2019). Components of professional competence of educators of pre-school educational institutions: pedagogical excellence, pedagogical creativity. Pedagogical sciences: reality and perspectives, 69, 5-9.

https://doi.org/10.31392/2311-5491/2019-69.1

Bakhov, I., Ryzhykov, V. And Kolisnyk, O. (2018). Leadership Abilities of a Military Manager, Professionalism of a Commander as the Guarantee of the Practice of Effective Activity of a Military Organization. International Journal of Engineering \& Technology, 7(4.38), 45-49. https://doi.org/10.14419/ijet.v7i4.38.24318

Buldu, D., \& Armagan, F. (2019). Determination of the opinions of prospective science teachers about the planned trip to the sugar factory. International Journal of Innovative Research in Education, 6(2): 21-39.

https://doi.org/10.18844/ijire.v6i2.4474

Cordeiro, E. de P. B., Marques, M. M. C., \& Costa, M. T. N. (2021). Socio-emotional education: paths to inspire studies, research and practices. Revista Tempos e Espaços em Educação, 14(33), e13729.

https://doi.org/10.20952/revtee.v14i33.13729 
Fedorov, A. A., Mialkina, E. V., Sedykh, E. P. S., \& Zhitkova, V. A. (2021). Model of managing the professionaleducational route of a future specialist. Revista Tempos e Espaços em Educação, 14(33), e16325.

https://doi.org/10.20952/revtee.v14i33.16325

Fedorov, A.A., Paputkova, G.A., Ilaltdinova, E.Y.,Filchenkova, I.F., \& Solovyev, M.Y. (2017). Model for employersponsored education of teachers: Opportunities and challenges. Man in India, 97(11), 101-114.

Krumsvik, R. J. (2014). Teacher educators' digital competence. Scandinavian Journal of Educational Research, 58(3), 269-280.

PETROVICI, C. (2014). Professional and Transversal Competences of Future Teachers for Preschool and Primary School Education. Procedia - Social and Behavioral Sciences, 142, 606. https://doi.org/10.1016/j.sbspro.2014.07.606

Kryshtanovych, M., Kryshtanovych, S., Stechkevych, O., Ivanytska, O., \& Huzii, I. (2020). Prospects for the Development of Inclusive Education using Scientific and Mentoring Methodsunder the Conditions of Post-Pandemic Society. Postmodern Openings, 11(2), 73-88. https://doi.org/10.18662/po/11.2/160

Kryshtanovych, S., Bilyk, O., Shayner, H., Barabash, O., \& Bondarenko, V. (2021). Study of the Experience of the Formation of Professional Competence in Future Managers of Physical Education and Sports. Revista Romaneasca Pentru Educatie Multidimensionala, 13(1), 162-176. https://doi.org/10.18662/rrem/13.1Sup1/390

Marek, M., Wu, W-C., \& Chew, C. S. (2020). Teacher Experiences in Converting Classes to Distance Learning in the COVID-19 Pandemic. International Journal of Distance Education Technologies, 19, 40-60.

https://doi.org/10.4018/IJDET.20210101.0a3

Orchard, J., Heilbronn, R., \& Winstanley, C. (2016). Philosophy for Teachers (P4T): Developing new teachers' applied ethical-decision making. Ethics and Education, 11(1), 42-54. https://doi.org/10.1080/17449642.2016.1145495

Roth K., Mollvik L., Alshoufani R., Adami R., Dineen K., Majlesi F., Peters M. \& Tesar M. (2020) Philosophy of education in a new key: Constraints and possibilities in present times with regard to dignity, Educational Philosophy and Theory, AHEAD-OF-PRINT, 1-32. https://doi.org/10.1080/00131857.2020.1851189

Received: 31 July 2021 | Accepted: 2 November 2021 | Published: 4 December 2021

This is an Open Access article distributed under the terms of the Creative Commons Attribution License, which permits unrestricted use, distribution, and reproduction in any medium, provided the original work is properly cited. 